\title{
Analysis of Subgroup Distribution and Discriminant Function Analysis in Children with Cerebral Palsy Based on Speech Language Profile Group
}

\author{
Pil Yeon Jeong, ${ }^{a}$ Hyun Sub Sim ${ }^{\mathrm{b}}$ \\ ${ }^{a}$ Ewha Womans University Center for Child Development and Disability, Seoul, Korea \\ ${ }^{b}$ Department of Communication Disorders, Ewha Womans University, Seoul, Korea
}

Correspondence: Hyun Sub Sim, PhD Department of Communication Disorders, Ewha Womans University, 52 Ewhayeodae-gil, Seodaemun-gu, Seoul 03760, Korea

Tel: $+82-2-3277-3538$

Fax: +82-2-3277-2122

E-mail: simhs@ewha.ac.kr

Received: April 3, 2021

Revised: April 20, 2021

Accepted: April 20, 2021

This work is based on the doctor's thesis of the first author.

\begin{abstract}
Objectives: This study aimed to identify the subgroups distribution of children with cerebral palsy (CP) by using Speech, Language Profile Group (SLPG), and examine discriminant factors that differentiate subgroups. Methods: Eighty-seven children aged 4-16 years with CP participated in the study (spastic 67, dyskinetic 4, ataxic 3, mixed 13). Data was collected from a speech production task (sustained vowel /a/, Assessment of Articulation and Phonology for Children, sentence repetition), language test (receptive vocabulary), and PIQ test (K-WISC-III, K-WIPPSI). Independent variables were maximum phonation time (MPT), intensity, speech rate, intelligibility, receptive vocabulary score, and cognition ability. For the analysis, children with CP were classified into six speech language profile groups; NSMILCT (no clinical speech motor involvement and age appropriate language, cognition abilities), NSMI-LCI (no clinical speech motor involvement and impaired language, cognition abilities), SMI-LCT (speech motor impairment and age appropriate language, cognition abilities), SMI-LCI (speech motor impairment and impaired language, cognition abilities), ANAR-LCT (anarthria and age appropriate language, cognition abilities), and ANAR-LCI (anarthria and impaired language, cognition abilities). Results: Descriptive study showed that of all children with CP, the proportion of NSMI-LCT was $11.5 \%$, NSMI-LCI was $8.0 \%$, SMI-LCT was $12.6 \%$, SMI-LCl was $19.5 \%$, ANAR-LCT was $11.5 \%$, and ANAR-LCl was $36.8 \%$. Very strong relationships were noted between SLPG and CFCS, and moderate relationships were noted between SLPG and GMFCS. Canonical discriminant function analysis revealed that the speech intelligibility variable accounted for $85.1 \%$, the speech rate variable was $9.7 \%$, and the language variable was $5.2 \%$. Conclusion: This study suggested that the SLPG classification system helps us to stratify the subgroups for understanding speech, language features in children with $C P$.
\end{abstract}

Keywords: Cerebral palsy, Speech, Language Profile Group (SLPG), Communication Function Classification System (CFCS), Intelligibility, Rate, Receptive vocabulary
뇌성마비 아동은 말, 언어 및 의사소통에서 다양한 어려움들을 경험한다(Hustad, Gorton, \& Lee, 2010; Hustad, Oakes, McFadd, \& Allison, 2016). 말 산출의 측면에서 보면 호흡, 발성, 조음, 말속도 및 말명료도 등에서 다양한 문제가 나타난다. 많은 선행연구들에 의하면 뇌성마비 아동의 호흡능력은 일반 아동의 수준에 비해 저 하되어 있고, 최대발성 지속시간(maximum phonation time, MPT)
도 일반 아동 보다 짧은 양상을 보인다(Jeong, Kim, Sim, \& Park, 2011; Kim \& Lee, 2018; Kim et al., 1998; Lee \& Kang, 2013; Wit, Maassen, Gabreëls, \& Thoonen, 1993). 발성의 측면에서 보면 음성 강도가 약하며(Jeong \& Sim, 2020a; Workinger, 2005), 음성 크기 가 $60 \mathrm{~dB}$ 이하(Kim et al., 1998; Lee \& Yoo, 2008; Lee \& Kang, 2013)이기 때문에 일반적 대화 상황에서 요구되는 음성강도에 비 
하면 약하다(Jeong \& Sim, 2017). 이렇게 음성 강도가 낮아지는 이 유는 성대긴장도 조절이나 성문하압의 적절한 생성과 배출 과정이 정상적으로 이루어지지 않기 때문이다(Kim \& Kim, 2013; Workinger, 2005). 뇌성마비 아동의 낮은 음성 강도는 말명료도에 부정 적인 영향을 미치는 무력성(asthenic voice) 척도와 높은 상관이 있 다고 밝혀졌다(Jeong \& Sim, 2017). 뇌성마비 아동은 조음 산출에 서도 어려움을 보이는데, 조음위치상 치조음과 성문음의 산출이, 조음방법상 마찰음과 유음의 산출이 어려우며, 생략이나 대치 오 류가 빈번하게 나타난다(Irwin, 1972; Nam, 2012; Platt, Andrews, Young, \& Quinn, 1980; Working \& Kent, 1991). 뇌성마비 아동의 전체 말속도(Jeong \& Sim, 2020b; Kim \& Lee, 2018)와 조음속도 (Jeong \& Sim, 2020b; Jeong, Sim, Jeong, \& Yim, 2016) 모두 느린데 이는 근육 및 운동능력이 저하되어 발화 속도 자체가 느리고, 호흡 이 짧아 심의 구간이 길어지기 때문이다(Hustad et al., 2010). 뇌성 마비 아동의 평가 및 중재에 있어서 말명료도는 매우 중요한 요소 로 경미한 수준부터 대부분의 발화를 알아듣기 힘든 수준까지 중 증도가 다양하다. 임상에서 뇌성마비의 중재 목표를 선정할 경우 신경생리학적 결함을 동반하는 장애군이기 때문에 정확한 말소리 산출보다는 말명료도 증진을 주요한 목표로 한다. 따라서 어떠한 요인들이 말명료도에 어떻게 영향을 미치는지 파악하는 것은 중요 하다(Allison \& Hustad, 2018). 말명료도에 영향을 미치는 요인으로 는 구강운동능력(Choi \& Sim, 2013; Jeong \& Sim, 2015), 발성능력 (Jeong \& Sim, 2017), 말속도(Jeong et al., 2016; Jeong \& Sim, 2020b) 등 다양하지만, 조음정확도를 가장 중요한 예측 변인으로 보고 있 다(Ansel \& Kent, 1992; Lee, Hustad, \& Weismer, 2014; Schölderle, Staiger, Lampe, Strecker, \& Ziegler, 2016).

뇌성마비 아동은 말 산출뿐만 아니라 언어능력에서도 어려움을 동반한다. 예들 들면, 수용 언어능력이나 어휘력에서 일반 아동에 비해 낮은 수행을 보이는데(Cockerill et al., 2013; Pennington, 1999; Pennington \& McConachie, 2001), 신체적인 움직임의 제한으로 인해 생애 초기 탐색과 체험을 통한 언어습득의 기회가 적고(Geytenbeek, Heim, Knol, Vermeulen, \& Oostrom, 2015), 모방능력도 결여되기 때문이다(Workinger, 2005). 평균발화길이, 어휘다양도, 어휘력뿐만 아니라(Hustad, Kristen, Emily, \& Katherine, 2014; Park \& Kang, 2012) 문장이해능력도 지체되어 있으며(Hustad et al., 2014; Sigurdardottir \& Vik, 2011) 지적능력이 낮은 경우에는 수 용 및 표현언어능력에서 결함이 더 많이 나타난다고 보고되고 있 다(Pirila et al., 2007). 뇌성마비 아동의 말, 언어문제를 분포비율로 살펴보면 약 $50 \%$ 정도에서 말운동장애를 보이고(Nordberg, Miniscalco, \& Lohmander, 2014), 언어나 인지적 결함이 동반되는 경우
도 50\% 정도가 되며(Himmelmann, Lindh, \& Hidecker, 2013; Sigurdardottir \& Vik, 2011), 약 76\%에서는 말장애, 언어장애와 함께 의사소통장애도 동반된다고 보고하고 있다(Hustad et al., 2010).

앞서 언급한 바와 같이 뇌성마비 아동은 말, 언어발달에서 다양 한 어려움을 보이지만, 다른 장애군과는 달리 자세 및 운동장애가 동반되기 때문에 재활의학 분야에서는 일차적으로 운동능력 중심 의 분류체계를 적용해 오고 있다. 뇌성마비에 대한 전통적인 분류 체계에는 대근육기능 분류체계(Gross Motor Function Classification System, GMFCS; Beckung \& Hagberg, 2002)가 대표적이다. 그러나 GMFCS와 말산출능력 간의 관계를 살펴보았을 때 발성능 력과 상관은 있으나 조음능력과는 상관이 없다고 보고되고 있어 (Nordberg et al., 2014), GMFCS의 분류에 기초해서 중재 목표를 수립하기에는 제한적인 정보를 가지고 있다고 볼 수 있다. 또한 재 활의학 분야에서는 운동장애의 생리학적 유형에 따라 경직형, 불 수의 운동형, 실조형 분류도 사용하고 있다. 생리학적 유형 간에는 말 특성의 차이를 나타내기도 하지만(Jeong \& Sim, 2020a; Nam, 2011; Nam \& Kwon, 2009; Nam, Ahn, \& Jung, 2009; Park et al., 2010; Workinger, 2005), 특성들이 중첩(overlap)되어 있어 유형 간 차이를 명확하게 구분하기 어려운 점도 있다(Hustad et al., 2010; Workinger \& Kent, 1991). 즉 호흡, 발성, 운율 측면에서는 큰 차이 가 없고(Love, 2000; Workinger, 2005, Workinger \& Kent, 1991), 조음 측면에서 차이가 보고되기도 하지만 조음오류 유형에 따른 차이가 크게 다르지 않아서(Nam \& Kwon 2009; Jun, 1995; Workinger \& Kent, 1991) 유형 간 말산출 특성을 명백하게 분리하기도 어렵다. 이렇듯 운동능력 중심의 분류체계로는 뇌성마비 아동의 말이나 언 어 특성을 구체적으로 반영하지 못하기 때문에, 실제 언어재활에 서 중재를 위한 의사결정을 할 때 필요한 정보를 얻기에 한계가 있 다. 따라서 뇌성마비 아동의 효과적인 중재를 위해서는 말, 언어능 력을 고려한 새로운 분류체계가 필요하다.

뇌성마비의 새로운 분류체계에 대한 논의는 2000년대 이후 활 발히 진행되었다(Bax, Goldstein, Rosenbaum, Leviton, \& Paneth, 2005; Hustad et al., 2010; Hustad et al., 2016; Rosenbaum, Paneth, Leviton, Goldstein, \& Bax, 2007). Bax 등(2005)은 새로운 분류체 계에는 뇌성마비의 결함이나 중증도 수준에 대한 특성을 상세하게 설명(description)할 수 있어야 하고, 재활에 따른 변화 양상이 예측 (prediction) 가능해야 하며, 다양한 상황에서 분류한 뇌성마비의 유형을 비교(comparison)할 수 있어야 하고, 마지막으로 변화에 대 한 평가(evaluation of change)가 포함되어야 한다고 주장하였다. 그러나 기존의 운동 중심의 분류체계에서는 말과 언어능력에 관한 설명이나 이를 통한 비교, 예측 및 변화에 대한 평가를 위한 정보가 
충분히 포함되어 있지 않다. 따라서 뇌성마비라는 장애를 더 잘 이 해하고, 적절히 중재하기 위해서는 전통적 분류체계에서 추가적인 요소가 필요하다(Bax et al., 2005; Rosenbaum et al., 2007).

새로운 분류체계에 대한 시도로써 말-언어 프로파일 그룹(SpeechLanguage Profile Group, SLPG)과 의사소통 기능 분류체계(Communication Function Classification System, CFCS)가 있다. SLPG 는 뇌성마비 아동의 말, 언어능력에 따른 분류체계로(Hustad et al., 2010; Hustad et al., 2016), Hustad 등(2010)은 4세 뇌성마비 아동을 대상으로 말산출 능력의 결함 유무와 언어/인지능력의 결함 유무에 따라 NSMI (no clinical speech motor involvement), SMI-LCT (speech motor impairment and age appropriate language, cognitive abilities), SMI-LCI (speech motor impairment and impaired language, cognitive abilities), ANAR (anarthria) 등 4가지 하위그 룹을 제시하였다. 그리고 말속도와 모음공간의 요인이 SLPG 분류 체계를 가장 잘 판별해 줄 수 있는 요인이며, 그다음으로 언어능력 과 말명료도가 주요 판별요인이라고 보고하였다(Hustad et al., 2010). 그러나 Hustad 등(2010)의 연구에서는 만 4 세 아동만을 대 상으로 하였고, 말문제를 동반하지 않는 그룹(NSMI)과 무발화 그 룹(ANAR)인 경우에 언어문제의 유무(LCI vs LCT)에 따른 분류 가 이루어지지 않았기 때문에 후속연구를 통해 전체 하위그룹을 살펴볼 필요가 있다. 따라서 6개의 하위그룹, 즉 SMI 그룹을 포함 하여 NSMI-LCT, NSMI-LCI, ANAR-LCT, ANAR-LCI 그룹으로 세분화하여 분류하고, 그 분포 양상을 확인해 볼 필요가 있다. 한편 다른 분류 체계인 $\mathrm{CFCS}$ 는 뇌성마비인이 화자와 청자로서 얼마나 효율적으로 의사소통하는지 알아보는 분류체계이다. 선행연구 (Park, Kim, \& Chae, 2014)에서는 생활연령 평균 8.12세의 학령기 뇌성마비 아동을 대상으로 뇌성마비의 생리학적 유형과 마비 부위 에 따른 분포비율만을 분석하였고, $\mathrm{CFCS}$ 와 다른 말, 언어능력 분 류체계와의 관련성에 대한 연구는 이루어지지는 않았다. 따라서 다양한 연령대의 아동을 대상으로 CFCS 분류체계를 적용해 보면 서 동시에 말, 언어능력 분류체계와의 관련성에 대해서도 알아볼 필요가 있다.

뇌성마비의 분류에 대한 새로운 패러다임이 필요한 이유는 다음 과 같다. 첫째, 전통적인 뇌성마비의 분류체계에서는 대근육 기능 의 정도, 근육결함 부위, 생리학적 유형 등에 따라 분류를 하고 있 으나 이러한 운동기능 중심의 분류체계에서는 뇌성마비 아동의 말, 언어능력과 관련된 특성을 충분히 설명해 주지 못하고 있다. 둘 째, 뇌성마비 아동마다 기저의 신경학적, 신체적인 손상의 정도가 다양할 뿐만 아니라 말, 언어문제의 특성에서도 다양한 차이가 나 타나는 이질적인 집단이기 때문에(Hustad et al., 2010) 이러한 차이
를 계층적으로 이해하는 것은 매우 중요하고(Allison \& Hutad, 2018), 이 요소들을 고려한 새로운 분류체계의 적용이 필요하다.

뇌성마비 아동을 위한 새로운 분류체계가 시도되고 있지만 국내 에서는 현재까지 이러한 분류체계에 대한 연구가 활발하게 이루어 지지 않았고, 임상에서도 보편적으로 사용하고 있지 않은 실정이 다. 말, 언어 결함에 따른 분류를 통해 역학적 분포(epidemiological perspective) 현황을 파악할 수 있고, 뇌성마비 아동에서 관찰되는 말, 언어 결함의 구체적인 양상을 확인해 볼 수 있을 것이다. 따라서 본 연구는 첫째, SLPG 하위그룹별 분포가 어떠한 지 살펴보고, SLPG 분류체계와 기존에 사용하고 있는 CFCS, GMFCS 분류체계 간에 상관은 어떠한 지 알아보고자 하였다. 둘째, SLPG 분류체계를 가 장 잘 판별해 줄 수 있는 요인이 무엇인지 알아보고 이를 통해 뇌성 마비 아동의 중재 목표 설정에 필요한 임상적 정보를 제공하고자 하였다.

\section{연구방법}

\section{연구대상}

본 연구에는 서울, 경기도 및 경상도 지역에 있는 생활연령 평균 9.25 세 $($ 표준편차 $=4.15$, 범위 $=4-16$ 세)의 뇌성마비 아동 87 명이 참 여하였다. 연구대상의 선정기준은 선행연구(Hustad et al., 2010)와 같이 뇌성마비로 진단받고, 청력이 정상 범주라고 보고한 아동을 포함시켰다. 이들은 모두 재활병원, 특수학교, 장애전담 어린이집 등에서 특수교육 및 재활치료를 받고 있는 아동들이며, 성별로는 남아 53명(60.92\%), 여아 34명(39.08\%)이 참여하였다. 뇌성마비 유 형별로는 경직형 67 명(77.01\%), 불수의운동형은 4 명 $4.6 \%$, 실조형 3 명(3.45\%), 혼합형 13명(14.94\%)이참여하였다.

\section{실험절차}

본 연구는 이화여자대학교 생명윤리위원회의 승인을 받았으며 (IRB No: 142-11), 법정 대리인 부모용 동의서와 읽기 및 쓰기가 가 능한 참여 아동에 한해 연구대상자용 동의서를 받고 진행하였다. 본 실험에 앞서 실험 절차의 문제점을 파악하기 위해 학령전기 아 동 1 명과 학령기 아동 2 명을 대상으로 예비실험을 실시한 후 본 실 험을 진행하였다. 본 실험의 검사 소요시간은 30 분- 1 시간 20 분이었 으며 검사횟수는 1 회에 모든 검사를 완료한 아동이 84 명이고, 피로 감이나 다음 일정 때문에 2 회에 걸쳐서 실시한 아동은 3 명이었다. 연구에 참여한 아동 가운데 보행이 가능한 아동은 연구자와 대각 선으로 책상에 앉아서 진행하였고, 보행이 어려운 경우에는 휠체어 로 이동한 다음 연구자와 나란히 앉거나 대각선으로 앉아서 진행 
하였다. 모든 실험은 주변 소음이 들리지 않는 각 기관의 조용한 장 소에서 실시하였고, 보호자의 요청에 따라 가정집에서 실시한 경우 에도 조용한 방에서 개별적으로 실시하였다.

실험 시작에 앞서 간단한 인사와자기소개를 한 후 검사를 실시하 였다. 연구과제의 평가는 말, 언어, 인지능력 평가 순으로 실시하였다.

모든 말산출 능력 과제의 수집은 마이크가 내장된 디지털녹음기 (ICD-UX512F, SONY)를 사용하였고, 아동의 입과 녹음기 간 거리 는 $10 \mathrm{~cm}$ 거리를 두고 녹음하였다. 말산출 능력의 평가 과제는 MPT, 아동용 발음평가 검사(Assessment of Phonology and Articulation for Children, APAC; Kim, Pae, \& Park, 2007), 문장 따라말하기 순 으로 실시하였다. MPT는 호흡능력의 평가를 위해 선행연구(Jeong et al., 2011; Lee \& Yoo, 2008; Park, Park, \& Kim, 2004)와 동일하게 모음 '아'를 3 회 연장 발성하도록 하였다. 연구자는 아동이 모방할 수 있도록 시범을 보여준 후 바른 자세로 앉아서 최대한 길게 발성 하도록 지시하였다. 자음정확도 및 말명료도 평가를 위해 APAC (Kim et al., 2007)의 37개 단어를 사용하였다. 그림을 보여주고 단 어 이름을 말하도록 하였고, 스스로 말하지 못하거나 틀리게 말하 는 경우에는 5 초간 기다린 후에 연구자를 따라말하도록 하였다. 말 속도(speaking rate) 측정을 위해 선행연구에서 사용한 문장 샘플 인 운반구(예: 베개가 저기 있다, 구두가 저기 있다)를 사용하였으 며(Han, Sung, Sim, \& Lee, 2013), 녹음한 소리를 듣고 따라말하도 록 하였다. 본 연구에서는 학령기 아동 가운데에도 읽기가 불가능 한 아동이 다수 포함되어 있어 따라말하기를 통해 말속도를 측정 하였다.

언어능력에 대한 평가는 수용 및 표현어휘력 검사(Receptive \& Expressive Vocabulary Test; REVT) 가운데 수용어휘력 검사를 사 용하였다(Kim, Hong, Kim, Jang, \& Lee, 2009). REVT 검사는 생 활연령 2-16세 이상을 대상으로 어휘발달수준을 평가하는 표준화 된 검사로 4 개의 그림 가운데 지시하는 단어에 해당하는 그림 가리 키기를 통해 실시하는 평가이다. 본 연구에서는 신체적인 움직임에
제약이 있는 아동이 다수 참여하였으므로 만약 손으로 가리키는 운동기능이 제한된 경우라면 1 번부터 4 번까지 번호가 매겨진 숫자 판을 보고 해당하는 숫자에 눈을 맞추도록 하거나, 연구자가 그림 을 가리키는 경우에 해당하는 단어가 맞으면 고개를 끄덕이게 하거 나 ‘예’라고 대답하고, 틀리면 고개를 가로젓거나 ‘아니오'라고 말하 도록 하는 등 필요한 경우에 보완적인 의사소통 방법을 추가하여 검사를 실시하였다.

인지능력을 평가하기 위해 생활연령 만 4;0세부터 6;11세 아동은 한국 웩슬러 아동지능검사(Korean-Wechsler Preschool and Primary Scale of Intelligence, K-WPPSI; Park, Kwak, \& Park, 1996)의 동 작성 지능검사를 사용하였다. 생활연령 만 7;0세부터 16;11세 아동 및 청소년은 K-WISC-III (Korean- Wechsler Intelligence Scale for Children-III; Kwak, Park, \& Kim, 2001)의 동작성 지능검사를 실 시하였다.

SLPG 하위그룹 분류를 위한 절차는 다음과 같다. 본 연구에서는 SLPG에 따른 하위그룹 분류를 위해 선행연구(Hustad et al., 2010) 에서 제안한 말, 언어 결함 유무에 따른 분류체계를 적용하되, 4 개 의 하위그룹으로 분류한 선행연구(Hustad et al., 2010; Hustad et al., 2016)를 보다 세부적으로 분류하고, 확장하여 6개 하위그룹으 로 분류하였다. SLPG 하위그룹에 대한 설명은 Table 1에 제시하였 다. 하위그룹 분류를 위한 의사결정 방법은 말문제가 없는 경우 NSMI (no clinical speech motor involvement), 말문제가 있는 경우 SMI (speech motor impairment), 연령에 적합한 주의력과 언어적 반응(구어, 비구어적 수단)을 보이는 경우 LCT (age appropriate language, cognition abilities), 주의력과 언어적 반응이 연령에 적 합하지 않는 경우 LCI (impaired language, cognition abilities), 기 능적으로 산출할 수 있는 단어가 없는 경우 ANAR (anarthria) 그 룹으로 할당하였다.

SLPG 하위그룹 할당에 대한 신뢰도 분석을 위해 전체 자료의 약 $10 \%$ 에 해당하는 자료의 일치 비율로 개인 내 신뢰도와 개인 간 신

Table 1. Description of Speech-Langue Profile Group

\begin{tabular}{ll}
\hline Subgroup & \multicolumn{1}{c}{ Description } \\
\hline NSMI-LCT & No evidence of speech motor involvement and age appropriate language, cognition abilities based on clinical assessment. \\
NSMI-LCl & No evidence of speech motor involvement and impaired language, cognition abilities based on clinical assessment. \\
SMI-LCT & Evidence of speech motor involvement and age appropriate language, cognition abilities based on clinical assessment. \\
SMI-LCI & Evidence of speech motor involvement and impaired language, cognition abilities based on clinical assessment. \\
ANAR-LCT & Unable to produce functional speech and age appropriate language, cognition abilities based on clinical assessment. \\
ANAR-LCl & Unable to produce functional speech and impaired language, cognition abilities based on clinical assessment. \\
\hline
\end{tabular}

NSMI-LCT = no speech motor involvement and age appropriate language, cognition abilities; NSMI-LCl= no speech motor involvement and impaired language, cognition abilities; SMI-LCT = speech motor impairment and age appropriate language, cognition abilities; SMI-LCl= speech motor impairment and impaired language, cognition abilities; ANAR-LCT = anarthria and age appropriate language, cognition abilities; ANAR-LCl=anarthria and impaired language, cognition abilities. 
뢰도를 측정하였다. 신뢰도 분석은 선행연구(Hustad et al., 2016)와 같이 2 명의 뇌성마비 전문 언어재활사가 실시하였다. 평가자 내 신 뢰도는 $100 \%$ 였으며 평가자간 신뢰도는 $90 \%$ 였다. 평가자간 일치하 지 않는 경우 논의를 통해 합의를 한 후 하위그룹에 할당하였다.

기능적 분류체계에 대한 평정은 $\mathrm{CFCS}$ 와 $\mathrm{GMFCS}$ 를 사용하였다. CFCS 평가는 뇌성마비 아동의 부모가 평정하도록 하였다. CFCS 는 총 5 개의 수준으로 이루어져 있으며 수준 I은 친숙하거나 친숙 하지 않은 의사소통 상대자와 효과적으로 청자와 화자의 역할을 수행하는 수준이고, 수준 II는 친숙하거나 친숙하지 않은 대화상 대자와 느리지만 효과적으로 의사소통 하는 수준을 반영한다. 수 준 III은 친숙한 대화상대자와 효과적으로 의사소통 하는 수준이 고, 수준 IV는 친숙한 대화상대자와 화자와 청자의 역할을 일관성 있게 바꾸지는 못하지만 때때로 친숙한 상대자와는 효과적으로 의 사소통 하는 수준을 의미한다. 수준 $\mathrm{V}$ 는 친숙한 대화상대자와의 의사소통도 어려우며 청자와 화자의 역할에 모두 제한이 있는 경 우로 분류하였다(Hidecker et al., 2011; Mei, Reilly, Reddihough,

Mensah, \& Morgan, 2014; Park, Kim, \& Chae, 2014).

GMFCS에 대한 정보는 의료차트를 통해 수집하였고, 의료차트 를 통한 수집이 불가한 경우 연구자가 분류하였으며, 재활의학과 전공의를 통해 확인 후 기록하였다. GMFCS는 총 5 단계로 이루어 져 있으며 수준 I은 아무런 제한 없이 보행이 가능한 단계, 수준 II 는 제한은 있지만 걸을 수 있는 단계, 수준 III은 체간의 지지 없이 보행 보조도구 등을 사용해 걸을 수 있는 단계, 수준 IV는 제한은 있지만 휠체어와 같은 다른 이동 수단을 사용하여 이동할 수 있는 단계, 수준 $\mathrm{V}$ 는 이동성에 심각한 제한이 있는 단계로 분류하였다.

\section{자료분석}

뇌성마비 아동의 말, 언어 및 인지능력에 대한 자료분석은 다음 과 같이 실시하였다. MPT는 모음 '아' 3 회 반복 측정값 중에서 최대 수행시간을 산출능력으로 분석하였다(Jeong et al., 2011; Lee \& Yoo, 2008; Park et al., 2004; Sawashima, 1966). MPT 분석은 Praat (version 6.0.30)의 음향 파형이 시작되는 부분과 끝나는 부분을 지 정하여 몇 초 간 발성이 유지되었는지 소수점 둘째 자리까지 측정 하였다. 음성 강도 또한 Praat (version 6.0.30) 프로그램에서 결과값 을 측정하였다. 전반적인 말속도의 측정은 선행연구(Hustad et al., 2010)와 같이 전체 말속도(overall speaking rate)로 측정하였다. 즉 파형의 시작점부터 끝 지점까지 총 발화시간을 측정하고, 음절 간 심(pause)을 분석에 포함하여 전체 말속도를 측정하였다. 총 발화 시간을 측정한 후 전체 발화 음절 수로 나누어 초당 말속도(syllable per second, SPS)를 측정하였다.
자음정확도와 말명료도 평가를 위해 APAC (Kim et al., 2007)의 37 개 단어를 사용하였다. 자음정확도는 전체 음소에서 정확하게 말한 음소의 비율로 측정하였다. 말명료도 평정을 위한 APAC 음 성 파일은 총 68 개였으며 2 개의 세트 $(34 \times 2)$ 로 구성하였다. 음성 파일은 Praat 프로그램을 이용하여 낱말 간 4 초의 휴지기간을 두 고 편집하였고, 순서효과와 학습효과를 통제하기 위해 화자의 말 명료도 수준을 고려하여 제시 순서를 역균형화(counterbalancing) 하였고, 편집한 단어는 무선화하여 배열하였다(Lee, Sung, Sim, Han, \& Song, 2012). 말명료도 평정을 위해 청력과 말, 언어능력에 문제가 없는 대졸 이상 학력의 정상 성인 10 명이 참여하였다. 이들 의 생활연령 평균은 35.12 세 $(\mathrm{SD}=4.52)$ 로 뇌성마비 아동의 발화나 $\mathrm{APAC}$ 검사 단어를 한 번도 들은 적이 없는 성인을 대상으로 하였 다. 말명료도 평정 자료는 평가자들이 알아듣기 편안한 음성 크기 로 제시하였다. 평가자들은 녹음된 말소리를 듣고 먼저 들리는 대 로 적고, 그 옆에는 들은 소리의 목표단어를 기록하며 마지막으로 명료하게 들리는 정도를 표시하도록 하였다. 전혀 알아들을 수 없 다면 0점, 매우 명료하면 6점으로 하여 7점 척도로 평정하도록 하였 다(Park et al., 2010). 전체 말명료도 평정치는 정확하게 목표단어를 알아들은 정답 문항에 대한 말명료도 평정치만을 사용하여 산출 하였다. 즉 말명료도의 산출 방법은 정답 문항의 명료도 평정 점수 의 합/(정답 문항 개수 $\times 6) \times 100$ 으로 하여 산출하였다(Park et al., 2010).

언어능력에 대한 측정은 REVT 수용어휘력 평가의 원점수를 종 속변인으로 사용하였다. 인지능력 평가는 K-WPPSI와 K-WISC-III 의 동작성 지능검사의 환산점수를 종속변인으로 하였다.

\section{통계처리}

연구문제의 검증을 위한 통계분석은 SPSS Statistics 21.0 (SPSS Inc, Chicago, IL, USA)을 사용하여 분석하였다. 분류체계 간 분포 를 알아보기 위해 기술통계를 사용하였고, SLPG, CFCS, GMFCS 에 따른 분포비율을 알아보기 위해 교차분석을 실시하였으며, 분 류체계별(SLPG, CFCS, GMFCS) 상관성분석은 Kendal의 tau를 사용하여 분석하였다. SLPG 하위그룹을 가장 잘 판별해 줄 수 있 는 요인이 무엇인지 알아보고자 단계적 판별분석(stepwise discriminant analysis)을 실시하였다.

\section{연구결과}

\section{SLPG 하위그룹별 분포 및 CFCS, GMFCS 간 상관분석}

SLPG 하위그룹에 따라 분포비율을 알아본 결과, NSMI-LCT는 
$11.5 \%$ (10/87)이었고, NSMI-LCI는 8.0\% (7/87), SMI-LCT는 $12.6 \%$ (11/87), SMI-LCI는 19.5\% (17/87), ANAR-LCT는 11.5\% (10/87), ANAR-LCI는 36.8\% (32/87)를 나타내었다. SLPG 하위그룹별 분포 비율은 Table 2에 제시하였다. 분포비율은 ANAR-LCI가 가장 높았 고, 다음으로 SMI-LCI, SMI-LCT, ANAR-LCT, NMSI-LCT, NSMI-LCI 순으로 나타났다.

SLPG 하위그룹별로 CFCS와 GMFCS와의 분포비율을 알아보 기 위해 교차분석을 실시한 결과는 Table 3 과 같다. CFCS I에서 NSMI-LCT 그룹의 비율이 50\% (5/10), CFCS V에서 ANAR-LCI 그 룹의 비율이 $84.0 \%(21 / 25)$ 를 차지하는 것으로 나타났다. CFCS II 에서 SMI-LCI는 25\% (7/28), CFCS III에서 SMI-LCI는 41.7\% (5/12), CFCS IV에서 ANAR-LCI는 41.7\% (5/12)를 나타내어 각 하위그룹 별로 다소 분산된 분포를 보이는 있는 것으로 나타났다. SLPG와
$\mathrm{CFCS}$ 간에는 .875 의 상관을 보였다 $(p<.001)$.

SLPG와 GMFCS 분포를 보면 GMFCS IV에서 ANAR-LCT의 비율이 $50 \%$ (2/4), CFCS V에서 ANAR-LCI가 50\% (28/56)의 비율 을 차지하였다. 그러나, GMFCS I, II, III에서는 SLPG 하위그룹과의 분포가 비일관적이고, 더 넓게 분산되어 있는 것으로 나타났다. SLPG 와 GMFCS 간에 상관은 .548로 나타났다 $(p<.001)$.

\section{SLPG 하위그룹 판별요인분석}

SLPG 하위그룹을 가장 잘 판별할 수 있는 변인을 검정하기 위해 말(MPT, 음성 강도, 말속도, 말명료도), 언어(수용어휘력), 인지능력 변인들을 독립변수로 하고, SLPG 그룹을 종속변수로 하여 판별분석 을 실시하였다. SLPG 하위그룹의 특성을 잘 판별할 수 있는 판별함 수를 도출하고, 독립변수의 상대적 기여도를 파악하기 위해 Willks

Table 2. Distribution of Speech-Langue Profile Group

\begin{tabular}{lcccccc}
\hline NSMI-LCT & NSMI-LCl & SMI-LCT & SMI-LCl & ANAR-LCT & ANAR-LCl & Total \\
\hline $10(11.5)$ & $7(8.0)$ & $11(12.6)$ & $17(19.5)$ & $10(11.5)$ & $32(36.8)$ & $87(100)$ \\
\hline
\end{tabular}

Values are expressed as number of participants (percentage).

NSMI-LCT = no speech motor involvement and age appropriate language, cognition abilities; NSMI-LCl= no speech motor involvement and impaired language, cognition abilities; SMI-LCT = speech motor impairment and age appropriate language, cognition abilities; SMI-LCl= speech motor impairment and impaired language, cognition abilities; ANAR-LCT = anarthria and age appropriate language, cognition abilities; ANAR-LCl = anarthria and impaired language, cognition abilities.

Table 3. Results of cross-tabulation analysis among the CFCS, GMFCS and SLPG

\begin{tabular}{|c|c|c|c|c|c|c|}
\hline \multirow{2}{*}{ SLPG } & \multicolumn{6}{|c|}{ CFCS } \\
\hline & Level I & Level II & Level III & Level IV & Level V & Total \\
\hline NSMI-LCT & $5(50.0)$ & $5(21.3)$ & $0(0)$ & $0(0)$ & $0(0)$ & $10(11.5)$ \\
\hline NSMI-LCI & $2(20.0)$ & $5(17.9)$ & $0(0)$ & $0(0)$ & $0(0)$ & $7(8.0)$ \\
\hline SMI-LCT & $2(20.0)$ & $6(21.4)$ & $1(8.3)$ & $0(0)$ & $2(8.0)$ & $11(12.6)$ \\
\hline SMI-LCI & $1(10.0)$ & $7(25.00)$ & $5(41.7)$ & $3(25.0)$ & $1(4.0)$ & $17(19.5)$ \\
\hline ANAR-LCT & $0(0)$ & $4(14.3)$ & $2(16.7)$ & $4(33.3)$ & $0(0)$ & $10(11.5)$ \\
\hline ANAR-LCl & $0(0)$ & $2(7.1)$ & $4(33.3)$ & $5(41.7)$ & 21 (84.0) & 32 (36.8) \\
\hline Total & $10(11.5)$ & $28(32.2)$ & 12 (13.8) & $12(13.8)$ & 25 (28.7) & $87(100)$ \\
\hline \multirow{2}{*}{ SLPG } & \multicolumn{6}{|c|}{ GMFCS } \\
\hline & Level I & Level II & Level III & Level IV & Level V & Total \\
\hline NSMI-LCT & $1(33.3)$ & $4(23.5)$ & $2(28.6)$ & $1(25.0)$ & $2(3.6)$ & $10(11.5)$ \\
\hline NSMI-LCI & 1 (33.3) & $3(17.6)$ & $3(42.9)$ & $0(0)$ & $0(0)$ & $7(8.0)$ \\
\hline SMI-LCT & $1(33.3)$ & $2(11.8)$ & $0(0)$ & $1(25.0)$ & $7(12.5)$ & 11 (12.6) \\
\hline SMI-LCI & $0(0)$ & $5(29.4)$ & $1(14.3)$ & $0(0)$ & 11 (19.6) & $17(19.5)$ \\
\hline ANAR-LCT & $0(0)$ & $0(0)$ & $0(0)$ & $2(50.0)$ & $8(14.0)$ & $10(11.5)$ \\
\hline ANAR-LCl & $0(0)$ & $3(17.6)$ & $1(14.3)$ & $0(0)$ & $28(50.0)$ & $32(40.2)$ \\
\hline Total & $3(3.4)$ & $17(19.5)$ & $7(8.0)$ & $4(4.6)$ & $56(64.4)$ & $87(100)$ \\
\hline
\end{tabular}

Values are expressed as number of participants (percentage).

CFCS = communication function classification system; $S L P G$ = speech language profile group; GMFCS = gross motor function classification system; NSMI-LCT=no speech motor involvement and age appropriate language, cognition abilities; NSMI-LCl=no speech motor involvement and impaired language, cognition abilities; SMI-LCT=speech motor impairment and age appropriate language, cognition abilities; SMI-LCl=speech motor impairment and impaired language, cognition abilities; ANAR-LCT=anarthria and age appropriate language, cognition abilities; ANAR-LCl = anarthria and impaired language, cognition abilities. 
Table 4. Results of discriminant function based on the SLPG

\begin{tabular}{|c|c|c|c|c|c|c|}
\hline \multirow{2}{*}{ Independent variable } & \multirow{2}{*}{ Input } & \multirow{2}{*}{ Wilk's Lambda (p) } & \multirow{2}{*}{$\eta^{2}$} & \multicolumn{3}{|c|}{ Correlation between discriminant function and independent variable } \\
\hline & & & & 1 & 2 & 3 \\
\hline Intelligibility & 1 & $.417(.000)$ & .583 & .849 & -.059 & -.524 \\
\hline Rate & 2 & $.365(.000)$ & .636 & .370 & .041 & -.175 \\
\hline Language (receptive vocabulary) & 3 & $.308(.000)$ & 692 & .295 & -.987 & .141 \\
\hline Intensity & & & .086 & .075 & .103 & .086 \\
\hline MPT & & & .327 & .124 & .206 & .327 \\
\hline Cognition & & & .098 & .037 & .133 & .098 \\
\hline Eigenvalue & & & & 3.817 & .435 & .235 \\
\hline Explanation variance & & & & 85.1 & 9.7 & 5.2 \\
\hline $\mathrm{RC}\left(\mathrm{Rc}^{2}\right)$ & & & & $.890(.792)$ & $.551(.304)$ & $.436(.190)$ \\
\hline Wilk's Lambda (p) & & & & $.117(.000)$ & $.564(.000)$ & $.810(.015)$ \\
\hline
\end{tabular}

SLPG = Speech-Language Profile Group, MPT = Maximum Phonation Time.

의 람다가 최소가 되도록 단계적 판별분석을 사용하여 분석하였다.

단계적 판별분석을 실시한 결과는 Table 4 와 같다. 음성 강도와 $\mathrm{MPT}$, 인지능력을 제외한 3 개의 독립변수인 말명료도, 말속도, 언 어(수용어휘력) 순으로 판별식에 투입되었으며 Wilks의 람다로 유 의수준을 확인한 결과, 3 개의 판별함수는 유의미한 것으로 나타났 다 $(p<.001)$. 첫 번째 판별함수는 말명료도로 설명분산의 비율은 $85.1 \%$ (고유값 $=3.817$, 정준상관 $=.890$ )이고, 두 번째 판별함수는 말속도로 설명분산의 비율은 $9.7 \%$ (고유값 $=.435$, 정준상관 $=.551$ ) 였다. 세 번째 판별함수는 언어능력(수용어휘력)으로 $5.2 \%$ (고유 값 $=.235$, 정준상관 $=.436)$ 의 설명분산 비율을 나타내었다. 또한 첫 번째 판별함수와 집단 간 상관은 .89 이고 공유분산의 비율은 $79.2 \%$ 였으며 두 번째 판별함수와 집단 간 상관은 . 551 이고 공유분 산의 비율은 $30.4 \%$, 세 번째 판별함수와 집단 간 상관은 .436 , 공유 분산의 비율은 $19 \%$ 로 나타났다. 따라서 SLPG 그룹을 판별하는데 가장 많은 기여를 하고 있는 것은 말명료도였으며 그다음으로 말속 도와 언어능력(수용어휘력)인 것으로 나타났다.

SLPG 하위그룹이 어느 정도 정확도로 분류되는지 분석한 결과, 도출된 판별함수에 의해 NSMI-LCT는 70\% (7/10), NSMI-LCI는 $100 \%$ (7/7), SMI-LCT는 72.7\% (8/11), SMI-LCI는 53.8\% (7/13), ANAR-LCT는 88.9\% (8/9), ANAR-LCI는 100\% (5/5)의 정확도를 나타 내었다. 전체 분류 정확도는 $76.36 \%$ (42/55)로 이러한 결과는 본 연 구의 판별함수가 우연에 의해 분류될 확률인 $50 \%$ 에 비해 $26.36 \%$ 더 정확하게 분류되었음을 의미한다.

\section{논의 및 결론}

본 연구에서는 생활연령 4-16세의 뇌성마비 아동 87명을 대상으
로 하여 SLPG 하위그룹별 분포비율을 파악하고, 기능적 분류체계 에 해당하는 SLPG, CFCS, GMFCS 간 상관관계를 살펴보았으며 SLPG 분류체계를 가장 잘 설명하는 판별요인에 대해 알아보았다. 연구결과를 토대로 다음과 같이 논의하였다.

\section{SLPG 하위그룹별 분포 비교 및 CFCS, GMFCS 간 상관분석}

SLPG 분류체계에 따른 분포비율을 살펴본 결과, NSMI-LCT 그 룹은 $11.5 \%$, NSMI-LCI는 $8.0 \%$, SMI-LCT는 $12.6 \%$, SMI-LCI는 $19.5 \%$, ANAR-LCT는 $11.5 \%$, ANAR-LCI는 36.8\%를 나타내었다. 하위그룹별 분포비율은 ANAR-LCI가 가장 높았고, 다음으로 SMI-LCI, SMI-LCT 순이었고, 그다음으로 ANAR-LCT와 NSMILCT는 동일한 비율을 보였으며, NSMI-LCI의 비율이 가장 낮았다. 이러한 결과는 말-언어문제가 없는 뇌성마비 아동부터 전혀 발화 를 할 수 없는 아동까지 그 분포가 다양하고, 범위가 넓다는 것을 반영한다(Smith \& Hustad, 2015).

분포비율을 요약해 보면 말과 언어문제를 동반하는 그룹(ANAR-LCI, SMI-LCI, 56.3\%)의 비율이 가장 높고, 말문제만 있는 그 룹(SMI-LCT, ANAR-LCT, 24.1\%)도 다음으로 높으나 말문제가 없 는 그룹(NSMI-LCT, NSMI-LCI, 19.5\%)이나 언어문제만 있는 그룹 (NSMI-LCI, 8\%), 말과 언어문제를 동반하지 않은 그룹(NSMI-LCT, $11.5 \%$ )의 비율은 상대적으로 낮다. 이와 같은 결과는 여러 연구들 을 통해 뇌성마비 아동이 말과 언어능력에 어려움을 보이고, 이러 한 문제가 의사소통에 영향을 미친다고 보고한 바와 같다(Bax, Tydeman, \& Flodmark, 2006; Himmelmann et al., 2013; Hustad et al., 2010, 2014, 2015; Nordberg et al., 2014; Sigurdardottir \& Vik, 2011). 대단위 연구를 통해 유럽의 뇌성마비 아동 약 $60 \%$ 가 의사소 
통 문제를 나타낸다고 보고한 경우(Bax et al., 2006)나 미국 2세 뇌 성마비 아동(Hustad et al., 2014) 약 $85 \%$ 에서 말과 언어문제가 함 께 나타낸다고 한 결과와도 유사하다. 또한 뇌성마비 아동의 $50 \%$ 이상이 말장애 및 언어장애를 동반한다는 선행연구(Himmelmann et al., 2013; Hustad, et al., 2010, 2016; Nordberg et al., 2014; Sigurdardottir \& Vik, 2011)를 지지하는 결과이다. 따라서 이러한 분포 비율을 고려할 때 뇌성마비 아동의 중재에서 말문제 우선 접근이 아니라 말과 언어문제를 동시에 고려할 필요가 있다는 것을 제안할 수있겠다.

본 연구에서는 선행연구(Hustad et al., 2010)와는 달리 6개의 하 위그룹으로 세분화하여 분석하였다. 즉 NSMI와 ANAR 그룹에서 언어문제 유무에 따라 LCT 와 LCI의 분포비율도 확인하였다. 결과 를 보면 말문제가 없는 그룹에서는 언어문제도 없는(NSMI-LCT, $11.5 \%>\mathrm{NSMI}-\mathrm{LCI} 8.0 \%$ ) 비율이 더 높았다. 즉 말문제 없이 언어문 제만 보이는 뇌성마비 아동의 비율이 높지 않다는 것을 반영한다. 이와는 반대로 ANAR에서는 언어문제도 같이 동반하는 그룹(AN-

AR-LCI, $36.8 \%>$ ANAR-LCT $11.5 \%)$ 의 비율이 매우 높았다. 이와 관련하여 중증의 마비말장애를 동반하는 무발화 뇌성마비 아동에 서 수용어휘에 더 제약이 있음을 지적한 바 있다(Mei et al., 2016). 또한 뇌성마비의 말문제가 언어발달에도 영향을 끼칠 수 있으며 (Geytenbeek et al., 2015), 뇌성마비 아동의 말과 언어문제는 독립 적으로 분리되지 않고, 상호 간에 결합되어 내적인 관련성이 있다 고도 제기하고 있다(Smith \& Goffman, 2004). 이는 뇌성마비가 추 체로계 및 추체외로계 손상으로 인하여 발생하는 장애군이기 때 문에, 말산출뿐만 아니라 언어발달과 관련된 운동신경 경로에도 손상이 나타날 가능성이 크기 때문으로 사료된다. 특히 본 연구에 서는 경직형 뇌성마비 아동의 비율이 높았는데 이는 양측 운동신 경로 결함과 관련 있기 때문에 손상 범위가 넓고, 중증도에도 심각 한 영향을 미칠 수 있기 때문으로 판단된다.

한편 ANAR-LCT 그룹은 말산출에서는 매우 제한적인 수행을 보이지만 언어능력은 보존되어 있는 집단으로 본 연구에서 약 $11.5 \%$ 에 해당하는 뇌성마비 아동이 여기에 속하였다. Smith와 Hustad (2015)는 특히 표현언어에 제약이 심할 때 보완대체의사소통(Augmentative and Alternative Communication, AAC)을 통한 중재를 고려하게 된다고 하였고, 이때 이해언어능력이 의사소통에서 중요 하게 기여한다고 하였다. 따라서 ANAR-LCT 그룹은 기능적인 발 화가 없어 표현언어에서 심한 제약이 있지만 이해능력은 보존된 그 룹으로 특히 주요한 $\mathrm{AAC}$ 사용자 후보군이라고 할 수 있겠다. 그러 므로 이 그룹을 대상으로 $\mathrm{AAC}$ 중재효과나 활용 어휘, 문해력 등에 관한 연구가 활발하게 진행되기를 기대해 본다.
본 연구에서는 SLPG와 다른 분류체계 간의 관련성에 대해서도 알아보았다. SLPG와 CFCS 간에는 높은 상관을 나타내었다. 선행 연구에서도 SLPG와 CFCS 간에는 .825 (Hustad et al., 2016), .874 (Choi, Park, Choi, Goh, \& Park, 2018)의 높은 상관을 보여주었다. SLPG는 뇌성마비 아동의 말, 언어 결함 유무에 따라 그룹 지어졌으 며 CFCS는 의사소통 수준에 따라 구분되는 분류체계이다. 이러한 결과는 말, 언어능력과 의사소통능력이 관련이 있다는 것을 반영 한다(Choi et al., 2018; Hustad et al., 2016; Pennington 1999; 2014a; 2014b). 이렇게 높은 상관을 보인 이유를 분포 양상에서 찾아보면, CFCS 수준 I과 NSMI-LCT, CFCS 수준 V와 ANAR-LCI에서 50\% 이상의 높은 비율을 차지하였다. 이는 말-언어장애가 없는 경우에 는 다양한 대화상대자와 어려움 없이 의사소통을 할 수 있는 비율 이 높지만, 말-언어장애가 동시에 나타나는 심도(severe)의 뇌성마 비 아동인 경우에는 친숙한 대화상대자와의 의사소통에서도 제한 이 있음을 반영하는 결과이다.

그러나 CFCS 수준 II, III, IV일 때는 SLPG의 여러 하위그룹으로 분산되어 나타났다. 이러한 결과는 SLPG에서는 말-언어장애의 중 증도가 고려되지 않았다는 점이 하나의 요인이 될 수 있을 것으로 생각된다. 즉 동일한 SMI 그룹 내에서도 말문제의 중증도는 다양했 기 때문이다. 또 다른 이유로는 말-언어문제가 동반되는 경우에 말 산출에는 상당한 제약이 있다 해도 다른 대체할 수 있는 의사소통 도구, 예를 들면 $\mathrm{AAC}$ 를 사용하여 말문제를 보완하면서 의사소통 할 수도 있기 때문에 의사소통 수준의 분포가 분산된 것으로 사료 된다. 이와 관련하여 선행연구(Kristoffersson, Sandberg, \& Holck, 2020)에서도 실제로 $\mathrm{AAC}$ 를 더 잘 활용할 때 $\mathrm{CFCS}$ 수준에서 더 효 과적으로 의사소통 하는 비율이 높고, 의사소통에 어려움을 보고 한 경우에는 $\mathrm{AAC}$ 활용이 원활하지 않았기 때문이라고 언급하였 다. 또한 말산출에 제한이 있다 해도 수용언어능력이 상대적으로 보존되어 있다면 의사소통 상황에서 상대적으로 제약을 적게 받을 수 있기 때문에 이러한 분포 간 분산이 나타나는 것으로 판단된다. $\mathrm{CFCS}$ 와 의사소통 방법과의 관련성에 대한 선행연구(Kristoffersson et al., 2020)에 따르면 CFCS 수준 I과 II에서는 의사소통 수단 이 구어(speech)이지만, 수준 III 이하로는 기능적인 의사소통에서 제약이 있는 경우에 소리, 눈 응시, 얼굴 표정, 제스처, 가리키기 등 을 다양하게 사용한다고 설명하였다. 이때 수용언어능력이나 어휘 력은 중요한 역할을 하게 되는데, 의사소통에서는 표현이 필요하지 만 잘 듣고 이해하는 것 또한 중요하기 때문이다. 또 다른 이유로 $\mathrm{CFCS}$ 는 부모평정으로 실시하였기 때문이다. 뇌성마비 아동의 부 모는 아동과 가장 밀접한 관계에 있으므로 익숙한 맥락 내에서 친 숙한 대화주제로 의사소통 하게 되므로 말-언어능력에 어려움이 
있더라도 의사소통이 가능하기 때문이다.

또 다른 분류체계인 GMFCS와 SLPG 간에는 중간 정도의 상관 을 보이는 것으로 나타났다. 국내 뇌성마비 아동을 대상으로 한 선 행연구(Choi et al., 2018)에서도 SLPG와 GMFCS 간에는 .485의 상 관을 제시하는데, $\mathrm{CFCS}$ 와의 관계에 비하면 그 상관 정도가 상대적 으로 낮다. 이러한 결과는 SLPG와 CFCS가 말, 언어 및 의사소통능 력이 반영된 것이라면(Choi et al., 2018), GMFCS는 대근육운동기 능 중심 분류체계이기 때문이다. 이러한 본 연구의 결과는 언어능 력은 소근육운동기능과 더 밀접한 관련이 있으며 대근육운동기능 과의 관련성은 낮다고 보는 선행연구(Kim, Carlson, Curby, \& Winders, 2016)와, GMFCS와 말산출능력 간의 상관성이 일관적이지 않다는 입장을(Nordberg et al., 2014) 지지한다.

하지만 GMFCS와 SLPG 간에 중간 정도의 상관을 보인 이유를 분포비율에서 찾아보면 GMFCS 수준 IV와 V에서 ANAR-LCT, ANAR-LCI 그룹과 일치하는 비율이 50\% 정도였고, 다른 하위그룹 에서는 여러 수준으로 분산되어 나타난다. Mei 등(2016) 역시 GMFCS IV, V수준에서는 언어능력과 유의한 상관을 보이는데 반해 GMFCS III은 언어문제와 관련이 없다는 결과를 제시하고 있다. 본 연구에서는 특히 ANAR-LCI 그룹의 경우에 GMFCS V단계에서 의 비율이 상대적으로 높았다. GMFCS V는 이동성에 심각한 제한 이 있어서 독립 이동이 어려운 단계이고, 체간과 머리의 조절에도 제한이 있는 단계이다(Palisano et al., 1997). 따라서 하지와 상지 모 두 운동성에 심각한 제약이 있으므로 말과 언어능력에도 제한이 따를 것으로 판단된다. 심도의 운동기능 저하가 있는 경우에 일차 적으로 말산출에 직접적인 영향을 미치지만, 언어발달에도 제약을 받을 가능성이 높아지게 된다. 운동기능의 저하로 인해 환경탐색의 기회가 줄어들 수밖에 없고, 자극을 처리하고 반응하는데 걸리는 시간도 많이 소요되며, 수술과 같은 의료적 처치가 반복되는 경우 에 일상생활에서의 다양한 언어학습의 기회가 줄어들 수밖에 없기 때문에 개념형성이나 어휘발달에도 제약이 따르게 되는 것이다 (Workinger, 2005).

본 연구의 결과는 SLPG와 CFCS 간에는 높은 상관을 보인 반면 에 GMFCS와 SLPG 간에는 중간 정도의 상관을 보여 상대적으로 관련성이 낮게 나타났다. 이러한 점을 고려할 때 대근육운동 분류 체계에 따라 뇌성마비 수준을 판별하던 기존의 분류체계에서 벗어 나 말, 언어나 의사소통능력에 따른 새로운 분류체계를 추가하여 적용될 필요가 있음을 시사한다(Choi et al., 2018).

\section{SLPG 판별요인 분석}

SLPG 하위그룹을 가장 잘 판별해 줄 수 있는 요인을 분석한 결
과, 말명료도가 첫 번째 판별함수로 나타났다. 선행연구(Hustad et al., 2010)에서는 세 번째 판별함수에 해당하였으나 본 연구에서는 첫 번째 판별함수로 SLPG 하위그룹을 구분하는 데 있어 가장 많 은 기여를 하는 것으로 나타났다. 이러한 결과가 나타난 이유들을 살펴보면 첫째, SLPG 하위그룹을 분류할 때 말문제 유무에 따라서 1차적 할당을 하였기 때문이다(Hustad et al., 2010). 둘째, 본 연구 에서는 말산출 능력 가운데에 말명료도에서 SLPG 하위그룹 간의 차이가 가장 명확하였는데, Appendix 1에 제시된 바와 같이 사후 분석을 통한 통계적 검정결과에서도 SLPG 모든 하위그룹에서 말 명료도는 그룹 간에 유의한 차이가 나타났고, 고유값 또한 다른 판 별함수에 비해 가장 높은 수치를 보였다. 고유값이 크다는 것은 집 단을 구분하는 데 있어 좋은 판별함수라는 것을 의미한다. 셋째, 선 행연구에서는 말명료도 평정 시에 Likert 척도를 사용하였으나 본 연구에서는 정확하게 알아들은 비율(\%)을 통해 측정하였다. 말명 료도 평정 시 Likert 척도에 비해 비율 척도가 더 신뢰롭게 말명료 도를 측정할 수 있는 것으로 보는데, 이러한 말명료도 평정 척도의 차이가 하위그룹 간 차이를 더 명확하게 함으로써 판별함수에 영 향을 미쳤을 것으로 보여 진다.

이와 같이 SLPG 하위그룹 별 판별요인을 분석한 결과에서 말명 료도가 제 1 판별함수로 도출되었다는 것은 뇌성마비를 대상으로 임상에 적용할 때 시사하는 바가 크다고 생각된다. 무엇보다 말명 료도는 마비말장애의 중재에 있어 일차적 목표이기 때문이다. 선행 연구들에서는 말명료도에 기여하는 여러 요인들을 음질(Jeong \& $\operatorname{Sim}, 2016$ ), 말속도 및 쉼(Jeong \& Sim, 2020b)과 같은 초분절적 요 소나 씹기 능력(Jeong \& Sim, 2015) 등으로 살펴보았으나, 본 연구 에서는 분절적 요소(Ansel \& Kent, 1992; Lee et al., 2014; Schölderle et al., 2016)를 통해 평정하였으며 이를 통해 뇌성마비 아동의 중 재 시 분절적 차원에서 말명료도의 향상이 중요하다는 것을 반복 확인하였다는 점에서 의의가 있다.

SLPG 하위그룹을 구분하는 두 번째 판별함수는 말속도로 나타 났다. 선행연구(Hustad et al., 2010)에서 말속도는 첫 번째 판별함 수에 해당되었고, 본 연구에서도 말속도가 SLPG 하위그룹의 주요 한 판별함수 가운데 하나라는 점은 선행연구와 유사하다. 이는 앞 서 언급한 바와 같이 SLPG 하위그룹을 분류할 때 말문제에 따라 우선 그룹을 할당을 하였기 때문에 말속도 또한 주요한 판별함수 에 해당될 수 있었을 것으로 사료된다. 그러나, 선행연구와 달리 두 번째 판별함수에 해당되는 이유로 Appendix 1의 사후분석 결과를 보면 확인할 수 있다. 말명료도는 4 개 그룹에서 차이를 나타낸데 비 해 말속도에서는 2개 그룹 간, MPT와 음성강도는 1 개 그룹에서만 유의한 차이를 나타내었다. 이러한 이유가 두 번째 판별함수로 도 
출되는데 영향을 미쳤을 것으로 판단된다.

말속도는 말산출 하부체계를 통합하는 전반적인 지표이면서

(Hustad et al., 2010; Yorkston, Beukelman, Strand, \& Bell, 1999), 마비말장애에 대한 임상적 판단을 하는데 일반 아동과 구분 짓는 주요한 예측변수이다(Allison \& Hustad, 2018; Jeong \& Sim, 2020b; Redford, 2014). 이러한 맥락에서 볼 때 SLPG 하위그룹에서 주요한 판별함수로 말속도가 도출된 것은 중요한 의의가 있을 것으로 판단 된다. 말속도가 하위그룹 판별에 두 번째 요인으로 나타난 것이 시 사하는 바는 앞서 언급한 말명료도와도 연관 지어 볼 수 있다. 최근 에 Jeong과 $\operatorname{Sim}(2020 \mathrm{~b})$ 의 연구에서는 심(pause)의 요소들은 말명 료도와 상관이 없지만, 말속도는 말명료도와 관련이 있다는 결과 를 보고하였다. 또한 말속도가 빠른 경우에 말명료도가 증가하는 결과를 제시하면서 말명료도 향상을 위해서는 발화 과정에서 말 산출의 속도와 조음의 정확도가 향상되어야함을 제안하였다.

세 번째 판별함수는 언어능력(수용어휘력)으로 나타났다. 이러 한 결과는 SLPG 하위그룹을 할당할 때 말문제 다음으로 언어문제 에 따라 할당하였기 때문에 결과에 반영된 것으로 보여진다(Hustad et al., 2010). 선행연구(Hustad et al., 2010)에서는 언어능력이 두 번째 판별함수로 그룹을 구분하는데 기여하는 것으로 나타났는 데, 선행연구와는 언어능력에 대한 평가 과제가 달랐기 때문에 판 별함수의 순서에 영향을 미쳤을 수도 있을 것으로 생각된다. 즉 선 행연구에서는 의미와 구문 요소를 포함한 전반적인 수용언어능력 으로 평가한 반면에 본 연구에서는 수용어휘력으로 측정한 결과이 다. 그러나, 주요한 판별함수에 포함되는 것은 선행연구과 유사한 결과라고 할수 있다.

지금까지 이루어지고 있는 뇌성마비 아동을 대상으로 한 연구 들을 보면 말산출 관련 요인들에 중점을 두는 경향이 있었고, 임상 에서도 호흡, 발성, 조음, 말속도, 구강운동 등 말산출을 중심으로 평가 및 중재가 이루어지고 있는 실정이다. 그러나 언어는 일상의 활동과 사회적 참여를 촉진하는 데 필수적인 역할을 하고(Mei et al., 2016), 학습능력을 최대화하기 위해서도 중요하다(Workinger, 2005). 뇌성마비 아동이 보이는 언어문제의 분포를 살펴보더라도 대략 36-74\%에서 언어적 결함이 보고된다(Pirila et al., 2007). Mei 등(2016)에 의하면 4-6세 뇌성마비 아동 84명을 대상으로 한 연구 에서 언어문제를 보이는 비율이 $61 \%$ 이고, 그 가운데 어휘력에서의 결함도 70\%가 해당된다고 하였다. Vaillant 등(2020)은 언어이해와 관련된 요소들을 ICF 모델에 근거하여 살펴보았는데, 활동과 참여 차원에서 상징놀이나 언어활동이 관련 있다고 지적하였다. 어휘력 은 의사소통, 언어능력 향상, 학업 수행력 등에 특히 중요한 역할을 하기 때문에 적절한 어휘의 습득은 매우 중요하다(Park \& Kang,
2012). 어휘력의 강점은 문장을 이루는 요소로써도 기능하지만 $\mathrm{AAC}$ 사용을 고려할 때 특히 중요한 요소이기도 하다. 예를 들어 뇌 성마비 아동 가운데에도 무발화이지만 언어능력이 보존되어 있는 ANAR-LCT 그룹인 경우에는 심도의 말문제를 보완하고 대체할 수 있는 다양한 도구적(aided), 비도구적(unaided) AAC를 활용하 여 의사소통을 촉진할 수도 있다. 따라서 말뿐만 아니라 언어능력 에 관한 다면적 평가는 뇌성마비 아동의 중재에서 유용한 정보를 제공해 줄 수 있을 것으로 판단된다. 뇌성마비 아동 가운데에도 언 어문제의 양상은 다양하기 때문에 언어능력에 대한 평가나 중재 역 시 간과하지 않아야 할 요소로 보여 진다.

SLPG 하위그룹의 판별요인 분석 결과를 종합해 보면, 본 연구에 서는 말명료도, 말속도, 언어능력(수용어휘력) 순으로 나타났다. 선 행연구(Hustad et al., 2010)에서는 말속도, 언어능력, 말명료도 순 으로 제시하였는데, 이렇게 판별함수의 순서가 다른 것은 본 연구 에서는 다양한 연령대의 아동이 참여하였고, 언어능력에 대한 평 가도구가 달랐으며 SLPG 하위그룹에서도 차이가 있었기 때문으 로 사료된다. 판별함수의 기여 정도가 상이하더라도 말명료도와 말속도, 언어능력은 두 연구 모두에서 주요한 판별요인으로 고려되 고 있다. 이러한 결과로 볼 때 뇌성마비 아동의 평가 및 중재 시에 이 세 가지 요소를 중요하게 고려할 필요가 있다는 것을 제안한다.

분류체계가 기여하는 점은 뇌성마비 아동의 특성이나 기능을 간단하게 파악할 수 있고, 설명할 수 있으며 필요한 중재 정보를 제 공하고, 집단 간 차이를 비교해 줌으로써 이에 따른 중재 목표를 선 정하고, 중재 결과를 예상할 수 있다는 점이다. 본 연구를 통해 뇌성 마비 아동의 말-언어 결함을 고려한 SLPG 분류체계를 적용해 보고, 하위그룹별 분포비율을 확인하였으며 기존의 분류체계와의 관련 성을 제시하였다. 또한 말명료도와 말속도 및 수용어휘력이 SLPG 하위그룹을 분류하는 주요한 판별함수임을 제시하였다. 이러한 결 과는 2001년 이후 새롭게 도입된 ICF 모델에 근거해 구조와 기능뿐 만 아니라 활동 및 참여 수준까지 고려하였다는 점에서 중요한 의 의라 할 수 있다. 또한 뇌성마비 중재를 위해서 말, 언어 및 의사소 통능력의 강점과 약점을 구체적으로 이해하는 것이 중요하게 요구 되는데(Mei et al., 2016), SLPG 하위그룹별 분석은 말, 언어능력에 따른 그룹 간 차이를 계층적으로 제시할 수 있고, 기존의 운동능력 중심 분류체계를 보완하였다는 점에서 중요한 의의가 있다.

본 연구의 제한점과 후속연구를 위한 제언을 하면 다음과 같다. 첫째, 뇌성마비 아동의 언어능력을 알아보기 위해 수용어휘력 검 사만을 실시하였다. 본 연구에는 만 4 세부터 16 세까지의 뇌성마비 아동이 참여하였으므로 만 13 세 이상인 경우 수용언어능력을 평 가할 수 있는 국내 평가도구가 제한적이어서 수용어휘력 검사를 
사용하였다. 후속연구에서는 동일한 연령대의 아동에게 공통적으 로 적용할 수 있는 언어능력 전반에 대한 검사를 실시해 봄으로써 연령 단위를 구분하여 SLPG 분류체계의 판별요인을 찾아볼 필요 가 있을 것으로 사료된다. 둘째, SMI 그룹에서는 뇌성마비 아동의 말, 언어능력의 중증도를 고려하지 못하였다. 추후연구에서는 중증 도를 고려하여 8 개 이상의 그룹으로 세분화한 연구가 이루어지기 를 기대한다. 셋째, 말속도 측정을 위해 문장 따라말하기 과제를 사 용하였다. 후속연구에서 음절이나 단어 수준으로 발화 단위를 다 양하게 설계한다면 다양한 중증도의 아동이 포함된 연구가 이루어 질 수 있을 것으로 사료된다. 넷째, 뇌성마비의 기능적 분류체계 가 운데 하나인 소근육기능 분류체계는 포함되지 않았다. 후속연구에 서 작업치료 분야에서 활용되고 있는 분류체계와의 비교 연구가 이루어진다면 더 많은 정보를 제공해 줄 수 있을 것으로 생각된다.

\section{REFERENCES}

Allison, K. M., \& Hustad, K. C. (2018). Data-driven classification of dysarthria profiles in children with cerebral palsy. Journal of Speech, Language, and Hearing Research, 61(12), 2837-2853.

Ansel, B., \& Kent, R. (1992). Acoustic-phonetic contrasts and intelligibility in the dysarthria associated with mixed cerebral palsy. Journal of Speech and Hearing Research, 35(2), 296-308.

Bax, M., Goldstein, M., Rosenbaum, P., Leviton, A., \& Paneth, N. (2005). Proposed definition and classification of cerebral palsy. Developmental Medicine \& Child Neurology, 47(8), 571-576.

Bax, M., Tydeman, C., \& Flodmark, O. (2006). Clinical and MRI correlates of cerebral palsy: the European Cerebral Palsy Study. The Journal of the American Medical Association, 296(13), 602-608.

Beckung, E., \& Hagberg, G. (2002). Neuro impairments, activity limitations, and participation restrictions in children with cerebral palsy. Developmental Medicine \& Child Neurology, 44(5), 309-316.

Choi, J. Y., Park, J., Choi, Y. S., Goh, Y. R., \& Park, E. S. (2018). Functional communication profiles in children with cerebral palsy in relation to gross motor function and manual and intellectual ability. Yonsei Medical Journal, 59(5), 677-685.

Choi, Y. J., \& Sim, H. S. (2013). Relationship between the maximal tongue and lip strength and percentage of correct consonants and speech intelligibility in dysarthric adults with cerebral palsy. Phonetics and Speech Sciences, 5(2), 11-22.

Cockerill, H., Elbourne, D., Allen, E., Scrutton, D., Will, E., McNee, A., Fair- hurst, C., \& Baird, G. (2013). Speech, communication and use of augmentative communication in young people with cerebral palsy: the SH \& PE population study. Child: Care, Health and Development, 40(2), 149-157.

Geytenbeek, J. J. M., Heim, M. J. M., Knol, D. L., Vermeulen, R. J., \& Oostrom, K. J. (2015). Spoken language comprehension of phrases, simple and compound-active sentences in non-speaking children with severe cerebral palsy. International Journal of Language and Communication Disorders, 50(4), 499-515.

Han, J. H., Sung, J. E., Sim, H. S., \& Lee, Y. M. (2013). Effects of speaking rate manipulation and the severity of dysarthria on speech intelligibility and acoustic parameters in persons with cerebral palsy. Journal of Speech-Language \& Hearing Disorders, 22(1), 35-54.

Hidecker, M. J., Paneth, N., Rosenbaum, P. L., Kent, R. D., Lillie, J., Eulenberg, J. B., ..., \& Tayor, K. (2011). Developing and validating the communication function classification system for individuals with cerebral palsy. Developmental Medicine \& Child Neurology, 53(8), 704-710.

Himmelmann, K., Lindh, K., \& Hideker, M. J. (2013). Communication ability in cerebral palsy: a study from the CP register of western Sweden. European Journal of Pediatric Neurology, 17(6), 568-574.

Hustad, K. C., Gorton, K., \& Lee, J. (2010). Classification of speech and language profiles in 4-year-old children with cerebral palsy: a prospective preliminary study. Journal of Speech, Language, and Hearing Research, 53(6), 1496-1513.

Hustad, K. C., Kristen, A., Emily, M., \& Katherine, R. (2014). Speech and language development in 2-year-old children with cerebral palsy. Developmental Neurorehabilitation, 17(3), 167-175.

Hustad, K. C., Oakes, A., McFadd, E., \& Allison, K. M. (2016). Alignment of classification paradigms for communication abilities in children with cerebral palsy. Developmental Medicine \& Child Neurology, 58(6), 597-604.

Irwin, O. C. (1972). Communication variables of cerebral palsy and mentally retarded children. Springfield, IL: C.C. Thomas.

Jun, H. S. (1995). A study on the articulation ability of cerebral palsied by the picture consonant articulation test. Communication Disorders, 18(1), 115132.

Jeong, J. O., Kim, D. Y., Sim, H. S., \& Park, E. S. (2011). The maximum phonation time and temporal aspects in Korean stops in children with spastic cerebral palsy. Phonetics and Speech Sciences, 3(1), 135-143.

Jeong, P. Y., \& Sim, H. S. (2020a). A comparative study of the acoustic characteristics of the vowel /a/ between children with spastic and dyskinetic cerebral palsy. Phonetics and Speech Sciences, 12(1), 65-74. 
Jeong, P. Y., \& Sim, H. S. (2020b). Characteristics of speech rate and pause in children with spastic cerebral palsy and their relationships with speech intelligibility. Phonetics and Speech Sciences, 12(3), 95-103.

Jeong, P. Y., Sim, H. S. (2015). The influence of chewing ability on speech intelligibility in children with spastic cerebral palsy. Special Education Research, 14(1), 63-80.

Jeong, P. Y., Sim, H. S. (2017). The effect of voice quality on speech intelligibility in children with spastic cerebral palsy. Phonetics and Speech Sciences, 9(4), 129-136.

Jeong, P. Y., Sim, H. S., Jeong, S. H., \& Yim, D. (2016). The relationship among articulation rate, intelligibility and working memory in children with spastic and flaccid dysarthria. Phonetics and Speech Sciences, 8(2), 41-48.

Kim, H., Carlson, A. G., Curby, T. W., \& Winsler, A. (2016). Relations among motor, social, and cognitive skills in pre-kindergarten children with developmental disabilities. Research in Developmental Disabilities, 53-54, 43-60.

Kim, H. K., Kim, W. H., Seo, J. H., Hong, K. H., Shin, H. K., \& Ko, D. H. (1998). Some clinical aspects of dysarthria. Speech Science, 3, 38-49.

Kim, J. O., \& Lee, C. Y. (2018). Comparison of speech mechanism between children with and without cerebral palsy. Journal of Speech-Language \& Hearing Disorders, 27(2), 147-157.

Kim, M. J., Pae, S., \& Park, C. I. (2007). Assessment of phonology and articulation for children (APAC). Incheon, Korea: Human Brain Research \& Consulting.

Kim, S. H., \& Kim, H. K. (2013). Acoustic characteristics of Korean alveolar sibilant 's', 's' according to phonetic contexts of children with cerebral palsy. Phonetics and Speech Sciences, 5(2), 3-10.

Kim, Y. T., Hong, G. H., Kim, K. H., Jang, H. S., \& Lee, J. Y. (2009). Receptive \& Expressive Vocabulary Test (REVT). Seoul, Korea: Seoul Community Rehabilitation Center.

Kristoffersson, E., Sandberg, A. D., \& Holck, P. (2020). Communication ability and communication methods in children with cerebral palsy. Developmental Medicine and Child Neurology, 62(8), 933-938.

Kwak, G. J., Park, H. W., \& Kim, C. T. (2001). Korean-Wechsler Intelligence Scale for Children-III (K-WISC-III). Seoul: Hakjisa.

Lee, G. S., \& Yoo, J. Y. (2008). The effect of respiration and articulator training programs on basic ability of speech production in cerebral palsy children. Speech Science, 15(3), 103-116.

Lee, J., Hustad, K. C., \& Weismer, G. (2014). Predicting speech intelligibility with a multiple speech subsystems approach in children with cerebral palsy. Journal of Speech, Language, and Hearing Research, 57(5), 1666-1678.
Lee, M. J., \& Kang, K. S. (2013). The effect of phonation and articulation development of the children with cerebral palsy after the respiratory training focused on music therapy intervention. The Journal of the Korean Association on Developmental Disabilities, 17(1), 1-21.

Lee, Y. M., Sung, J. E., Sim, H. S., Han, J. H., \& Song, H. N. (2012). Analysis of articulation error patterns depending on the level of speech intelligibility in adults with dysarthria. Korean Journal of Communication \& Disorders, 17(1), 130-142.

Love, R. J. (2000). Childhood motor speech disability. Boston: Allyn \& Bacon.

Mei, C., Reilly, S., Reddihough, D., Mensah, F., \& Morgan, A. (2014). Motor speech impairment, activity, and participation in children with cerebral palsy. International Journal of Speech-Language Pathology, 16(4), 427-435.

Mei, C., Reilly, S., Reddihough, D., Mensah, F., Pennington, L., \& Morgan, A. (2016). Language outcomes of children with cerebral palsy aged 5 years and 6 years: a population-based study. Developmental Medicine and Child Neurology, 58(6), 605-611.

Nam, H. W. (2011). The characteristics of intensity variations in diadochokinesis in the speakers with cerebral palsy. Journal of Speech-Language \& Hearing Disorders, 20(1), 157-171.

Nam, H. W. (2012). The characteristics of articulation errors in speakers with cerebral palsy by the reading task. Journal of Psychology and Behavior, 4(1), 41-51.

Nam, H. W., Ahn, J. B., \& Jung, H. (2009). The auditory-perceptual characteristics of articulation and prosody by the types of cerebral palsy in reading tasks. Journal of Speech-Language \& Hearing Disorders, 18(4), 91-103.

Nam, H. W., \& Kwon, D. H. (2009). A comparative study of the characteristics of the subsystems for speech production by the types of the cerebral palsy. Journal of Speech-Language \& Hearing Disorders, 18(2), 17-50.

Nordberg, A., Miniscalco, C., \& Lohmander, A. (2014). Consonant production and overall speech characteristics in school-aged children with cerebral palsy and speech impairment. International Journal of Speech-Language Pathology, 16(4), 386-395.

Palisano, R., Rosenbaum, P., Walter, S., Russell, D., Wood, E., \& Galuppi, B. (1997). Development and reliability of a system to classify gross motor function in children with cerebral palsy. Developmental Medicine and Child Neurology, 39(4), 214-223.

Park, E. Y., Kim, W. H., \& Chae, S. J. (2014). Reliability and validity on Korean version of Communication Function Classification System (CFCS) for individuals with cerebral palsy. Korean Journal of Physical, Multiple, \& Health Disabilities, 57(3), 185-302. 
Park, H. W., Kwak, G. J., \& Park, K. B. (1996). Korean Wechsler Preschool \& Primary Scale of Intelligence (K-WPPSI). Seoul: Special Education.

Park, J. E., Kim, H., Shin, J. C., Choi, H. S., Sim, H. S., \& Park, E. S. (2010). Speech evaluation variables related to speech intelligibility in children with spastic cerebral palsy. Phonetics and Speech Sciences, 2(4), 193-212.

Park. J. E., Park, E. S., \& Kim, H. (2004). A study of acoustic characteristics of vowels in preschool cerebral palsy children with spastic diplegia. Korean Journal of Communication \& Disorders, 9(2), 116-128.

Park, S. H., \& Kang, E. H. (2012). Comparative study on word diversity of children with cerebral palsy and normal children. Korean Journal of Physical, Multiple, \& Health Disabilities, 55(1), 183-196.

Pennington, L. (1999). Assessing the communication skills of children with cerebral palsy: does speech intelligibility make a difference?. Child Language Teaching and Therapy, 15(2), 159-169.

Pennington, L. (2014a). Development of communication by young people with cerebral palsy. Developmental Medicine \& Child Neurology, 56(10), 951-959.

Pennington, L. (2014b). Cerebral palsy and communication. Pediatrics and Child Health, 18(9), 405-409.

Pennington, L., \& McConachie, H. (2001). Interaction between children with cerebral palsy and their mothers: the effect of speech intelligibility. International Journal of Language Communication Disorders, 36(3), 371-393.

Pirila, S., van der Meere, J., Pentikainen, T., Ruusu-Niemi, P., Korpela, R., Kilpinen, J., \& Nieminen, P. (2007). Language and motor speech skills in children with cerebral palsy. Journal of Communication Disorders, 40(2), 116128.

Platt, L. J., Andrews, G., Young, M., \& Quinn, P. T. (1980). Dysarthria of adult cerebral palsy: I. Intelligibility and articulatory impairment. Journal of Speech and Hearing Research, 23(1), 28-40.

Redford, M. A. (2014). The perceived clarity of children's speech varies as a function of their default articulation rate. The Journal of the Acoustical Society of America, 135(5), 2952-2963.

Rosenbaum, P., Paneth, N., Leviton, A., Goldstein, M., \& Bax, M. (2007). A report: the definition and classification of cerebral palsy. Developmental Medicine \& Child Neurology, 49(s108), 8-14.

Sawashima, M. (1966). Measurements of the phonation time. Japanese Journal of Logopedics Phoniatrics, 7, 23-29.

Schölderle, T., Staiger, A., Lampe, R., Strecker, K., \& Ziegler, W. (2016). Dysarthria in adults with cerebral palsy: clinical presentation and impacts on communication. Journal of Speech, Language, and Hearing Research, 59(2), 216-229.

Sigurdardottir, S., \& Vik, T. (2011). Speech, expressive language, and verbal cognition of preschool children with cerebral palsy in Iceland. Developmental Medicine \& Child Neurology, 53(1), 74-80.

Smith, A., \& Goffman, L. (2004). Interaction of language and motor factors in speech production. In Maasen, B., Kent, R. D., Peters, H. F. M., van Leishout, P. H. H., Hulstijin, W. (Eds.). Speech motor control in normal and disordered speech (pp. 227-252). Oxford, UK: Oxford University Press.

Smith, A. L., \& Hustad, K. C. (2015). AAC and early intervention for children with cerebral palsy: parent perceptions and child risk factors. Augmentative and Alternative Communication, 31(4), 336-350.

Wit, J., Maassen, B., Gabreëls, F. J., \& Thoonen, G. (1993). Maximum performance tests in children with developmental spastic dysarthria. Journal of Speech and Hearing Research, 36(3), 452-459.

Workinger, M. S. (2005). Cerebral palsy resource guide for speech-language pathologists. Clifton Park, NY: Thomson Delmar Learning.

Workinger, M. S., \& Kent, R. D. (1991). Perceptual analysis of the dysarthrias in children with athetoid and spastic cerebral palsy. In C. A. Moore, K. M. Yorkston, \& D. R. Beukelman (Eds.), Dysarthria and apraxia of speech: perspectives on management (pp. 109-126). Baltimore, MD: Brookes.

Yorkston, K. M., Beukelman, D. R., Strand, E. A., \& Bell, K. R. (1999). Management of motor speech disorders in children and adults. Austin, TX: Pro-Ed. Vaillant, E., Geytenbeck, J. J. M., Jansma, E. P., Oostrom, K. J., Vermeulen, R. J., \& Buizer, A. I. (2020). Factors associated with spoken language comprehension in children with cerebral palsy: a systematic review. Developmental Medicine \& Child Neurology, 62(12), 1363-1373. 
Pil Yeon Jeong, et al. • Subgroup distribution in children with $\mathrm{CP}$

Appendix 1. Post hoc analysis of speech intelligibility, speech rate, MPT, intensity, receptive vocabulary by SLPG subgroup

\begin{tabular}{|c|c|c|c|c|c|c|}
\hline SLPG & Subgroup & Intelligibility & Rate & MPT & Intensity & Vocabulary \\
\hline \multirow[t]{5}{*}{ NSMI-LCT } & NSMI-LCl & & & & & $* * *$ \\
\hline & SMI-LCT & $* * *$ & & $* * *$ & & \\
\hline & SMI-LCI & $* * *$ & & $* * *$ & & $* * *$ \\
\hline & ANAR-LCT & $* * *$ & $* * *$ & $* * *$ & $* * *$ & \\
\hline & ANAR-LCl & $* * *$ & $* * *$ & $* * *$ & $* * *$ & $* * *$ \\
\hline \multirow[t]{4}{*}{ NSMI-LCl } & SMI-LCT & $* * *$ & & & & $* * *$ \\
\hline & SMI-LCI & $* * *$ & & & & \\
\hline & ANAR-LCT & $* * *$ & $* * *$ & & & $* * *$ \\
\hline & ANAR-LCI & $* * *$ & $* * *$ & & & $* * *$ \\
\hline \multirow[t]{3}{*}{ SMI-LCT } & SMI-LCl & & & & & $* * *$ \\
\hline & ANAR-LCT & $* * *$ & & & & \\
\hline & ANAR-LCI & $* * *$ & & & & $* * *$ \\
\hline \multirow[t]{2}{*}{ SMI-LCl } & ANAR-LCT & $* * *$ & & & & $* * *$ \\
\hline & ANAR-LCl & $* * *$ & & & & \\
\hline ANAR-LCT & ANAR-LCI & & & & & $* * *$ \\
\hline
\end{tabular}

NSMI-LCT = no speech motor involvement and age appropriate language, cognition abilities; NSMI-LCl= no speech motor involvement and impaired language, cognition abilities; SMI-LCT = speech motor impairment and age appropriate language, cognition abilities; SMI-LCI = speech motor impairment and impaired language, cognition abilities; ANAR-LCT = anarthria and age appropriate language, cognition abilities; ANAR-LCl = anarthria and impaired language, cognition abilities .

${ }^{* * *} p<.001$. 


\section{국문초록}

\section{Speech Language Profile Group (SLPG) 분류체계에 따른 뇌성마비 아동의 하위그룹 분포 및 판별요인 분석 정필연 · 심현섭 \\ ${ }^{1}$ 이화여자대학교 아동발달센터, ${ }^{2}$ 이화여자대학교 대학원 언어병리학과}

배경 및 목적: 본 연구는 Speech Language Profile Group (SLPG) 하위그룹별 뇌성마비 아동의 분포를 알아보고, 이러한 분류체계를 가장 잘 판별해 줄 수 있는 요인이 무엇인지 알아보고자 하였다. 방법: 본 연구에는 4-16세 뇌성마비 아동 87명(경직형 67명, 불수의 운 동형 4명, 실조형 3 명, 혼합형 13 명)이 참여하였다. 평가 과제는 말능력(모음연장발성, 아동용 발음평가, 문장 따라말하기), 언어능력(수 용어휘력 검사), 인지능력(동작성 지능검사) 검사였고, 이 과제를 통해 최대발성 지속시간, 음성강도, 말명료도, 말속도, 수용어휘력 및 인지능력을 측정하였다. 기능적 분류를 위해 CFCS와 GMFCS 평정을 실시하였다. SLPG 하위그룹은 말장애 유무, 언어문제 유무에 따 라 말과 언어문제가 없는 NSMI-LCT, 말문제는 없지만 언어문제가 있는 NSMI-LCI, 말문제가 있지만 언어문제는 없는 SMI-LCT, 말과 언어문제가 있는 SMI-LCI, 무발화이지만 언어문제는 없는 ANAR-LCT, 무발화이면서 언어문제가 있는 ANAR-LCI 등 6개 그룹으로 나누어 분석하였다. 결과: 첫째, SLPG 하위그룹별 분포비율은 NSMI-LCT는 $11.5 \%$, NSMI-LCI $8.0 \%$, SMI-LCT $12.6 \%$, SMI-LCI $19.5 \%$, ANAR-LCI $11.5 \%$, ANAR-LCI $36.8 \%$ 를 나타내었다. SLPG와 CFCS 간에는 .875, SLPG와 GMFCS 간에는 . 548 의 상관을 나타 내었다. 둘째, SLPG 하위그룹을 가장 잘 판별하는 함수는 말명료도, 말속도, 수용어휘력 순으로 나타났다. 논의 및 결론: SLPG 하위그 룹별 분석을 통해 말, 언어능력에 따른 그룹 간 분포비율을 제시하였고, 기존의 운동능력 중심의 분류체계를 상호보완할 수 있는 말, 언 어 및 의사소통능력에 근거한 분류체계의 적용이 필요함을 시사하였다.

핵심어: 뇌성마비, SLPG 분류체계, CFCS, 말명료도, 말속도, 수용어휘력

본 연구는 제 1 저자의 박사학위논문을 수정보완 하였음.

\section{참고문헌}

곽금주, 박혜원, 김청택 (2001). 한국 웩슬러 아동지능검사-3판. 서울: 학지사.

김민정, 배소영, 박창일 (2007). 아동용 발음평가(APAC). 인천: 휴브알엔씨.

김숙희, 김현기 (2013). 뇌성마비 아동의 음성 환경에 따른 치경마찰음 'ㅅ', 'ㅆ'의 음향학적 특성. 말소리와음성과학, 5(2), 3-10.

김영태, 홍경훈, 김경희, 장혜성, 이주연 (2009). 수용 및 표현어휘력검사(REVT). 서울: 서울장애인복지관.

김재옥, 이조영 (2018). 뇌성마비 아동과 일반 아동의 말산출 하부 체계 구조 및 기능 비교. 언어치료연구, 27(2), 147-157.

김현기, 김완호, 서정환, 홍기환, 신효근, 고도흥 (1998). 마비성 조음장애의 임상적 양상에 관한 고찰. 음성과학, 3,38-49.

남현욱 (2011). 뇌성마비 화자의 교호운동의 강도변화 특성. 언어치료연구, 20(1),157-171.

남현욱 (2012). 읽기과제에서 나타난 뇌성마비 화자의 조음오류 특성. 심리행동연구, 4(1),41-51.

남현욱, 권도하 (2009). 뇌성마비 유형별 구어산출 하위체계 특성비교. 언어치료연구, 18(2), 17-50.

남현욱, 안종복, 정훈 (2009). 읽기과제에서의 뇌성마비 유형별 조음 및 운율의 청지각적 특성. 언어치료연구, 18(4), 91-103.

박혜원, 곽금주, 박광배 (1996). 한국 웩슬러 유아지능검사. 서울: 도서출판 특수교육.

박선희, 강은희 (2012). 뇌성마비아동과 일반아동의 어휘다양도 비교연구. 지체·중복· 건강장애연구, 55(1), 183-196.

박은영, 김원호, 채수정 (2014). 한국판 의사소통 기능 분류 체계의 신뢰도 및 타당도 검증. 지체·중복· 건강장애연구, 57(3), 185-302.

박지은, 김향희, 신지철, 최홍식, 심현섭, 박은숙 (2010). 경직형 뇌성마비아동의 말명료도와 관련된 말평가변인. 말소리와음성과학, 2(4), 193-212.

박지은, 박은숙, 김향희 (2004). 학령전기 경직형 하지마비 아동이 산출한 모음의 음향 음성학적 특징. 언어청각장애연구, 9(2), 116-128.

이금숙, 유재연 (2008). 호흡 및 조음기관 훈련 프로그램이 뇌성마비 아동의 말 산출 기초능력에 미치는 효과. 음성과학, 15(3), 103-116. 
이미진, 강경선 (2013). 호흡훈련중심의 음악치료중재가 뇌성마비 아동의 발성 및 조음발달에 미치는 영향. 발달장애연구, 17(1), 1-21.

이영미, 성지은, 심현섭, 한지후, 송한내 (2012). 마비말장애인의 조음오류 유형에 따른 말명료도 분석. 언어청각장애연구, 17(1), 130-142.

전헌선 (1995). 그림자음검사(PACT)에 나타난 뇌성마비 학생의 조음능력. 난청과 언어장애연구, 18(1), 115-132.

정진욱, 김덕용, 심현섭, 박은숙 (2011). 경직형 뇌성마비 아동의 최대발성지속시간과 파열음 산출 시 조음시간 특성 비교. 말소리와 음성과학, 3(1),

135-143.

정필연, 심현섭 (2015). 경직형 뇌성마비 아동의 씹기능력에 따른 말명료도의 변화. 특수교육, 14(1), 63-80.

정필연, 심현섭 (2017). 뇌성마비 아동의 음질에 따라 말명료도에 미치는 영향 말소리와 음성과학, 9(4), 129-136.

정필연, 심현섭, 정숙회, 임동선 (2016). 경직형과 이완형 마비말장애아동에서 조음속도와 말명료도 및 작업기억능력 간의 관계. 말소리와 음성과학,

$8(2), 41-48$.

정필연, 심현섭 (2020a). 경직형과 불수의운동형 뇌성마비아동의/아/ 모음 음향학적 비교. 말소리와음성과학, 12(1), 57-66.

정필연, 심현섭 (2020b). 경직형 뇌성마비 아동의 하위그룹별 말속도와 쉼의 특성 및 말명료도와의 관계. 말소리와음성과학, 12(3), 95-103.

최여진, 심현섭 (2013). 뇌성마비로 인한 마비말장애 성인의 최대 혀 및 입술 강도와 자음정확도 및 말명료도와의 관계. 말소리와 음성과학, 5(2), 11-

22.

한지후, 성지은, 심현섭, 이영미 (2013). 말속도 조절 및 중증도가 마비말장애화자의 말명료도와 음향학적 파라미터에 미치는 영향. 언어치료연구, 22(1), 35-54.

\section{ORCID}

정필연(제1저자, 책임연구원 https://orcid.org/0000-0003-3447-0580); 심현섭(교신저자, 교수 https://orcid.org/0000-0002-4710-3678) 